\title{
FORMULASI MEDIA ALTERNATIF DARI KULIT SINGKONG, PISANG, DAN WHEY UNTUK Lactobacillus bulgaricus
}

\author{
[Formulation of Alternative Media from Cassava, Banana, and Whey \\ for Lactobacillus bulgaricus]
}

\section{Moch. Wachid, Yasmin Nurinbaity, Noor Harini, Elfi Anis Saati, dan Vritta Amroini Wahyudi*}

Program Studi Teknologi Pangan, Fakultas Pertanian-Peternakan, Universitas Muhammadiyah Malang, Malang

Diterima 20 Januari 2020 / Disetujui 28 April 2021

\begin{abstract}
De Man Rogose and Sharpe (MRS) growth medium is a specific growth medium for lactic acid bacteria $(L A B)$ but has a relatively expensive price. This can be overcome by making alternative media from waste materials. This study used Lactobacilus bulgaricus to represent $L A B$ analyzed for growth. The research aims to formulate alternative media from the waste of cassava peels, banana peels, and tofu whey; determine the best formulation based on the growth parameters of $L$. bulgaricus; apply the $L$. bulgaricus in soygurt making and analyze the quality of the resulting yogurt. The results showed the composition of cassava peel: banana peel $(75: 25 \mathrm{w} / \mathrm{w})$ with the addition of urea $1.5 \%$ as the best formulation. This formula yields a total $L A B$ of $8.6 \times 106 \mathrm{CFU} / \mathrm{mL}$. The total $L A B$ in the alternative medium was higher than that in MRS control at $1.7 \times 10^{6} \mathrm{CFU} / \mathrm{mL}$. Soygurt produced from $L A B$ as a result of growth from the best media [cassava peel+banana peel $(75: 25)$ with the addition of $1.5 \%$ urea] resulted in a fat content

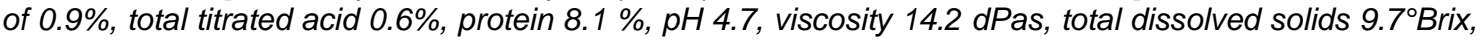
brightness $(L) 64.3$, and yellow-blue $(b+)$ 10.1. These fat content, total titrated acid, and protein are in accordance with SNI for yogurt 2981: 2009.
\end{abstract}

Keywords: alternative media, banana peel, cassava peel, Lactobacillus bulgaricus, whey

\begin{abstract}
ABSTRAK
Media pertumbuhan de Man Rogose and Sharpe (MRS) merupakan media pertumbuhan yang spesifik untuk bakteri asam laktat (BAL) namun memiliki harga yang relatif mahal. Hal tersebut bisa diatasi dengan pembuatan media alternatif dari bahan dasar limbah. Penelitian ini menggunakan Lactobacilus bulgaricus untuk mewakili BAL yang dianalisis pertumbuhannya. Penelitian bertujuan untuk memformulasi media alternatif dari limbah (kulit singkong, kulit pisang, dan whey tahu), menentukan formulasi terbaik berdasarkan parameter pertumbuhan L. bulgaricus, mengaplikasikan L. bulgaricus pada pembuatan yogurt, dan menganalisis kualitas soygurt yang dihasilkan. Hasil penelitian menunjukkan komposisi kulit singkong:kulit pisang $(75: 25 \mathrm{~b} / \mathrm{b})$ dengan penambahan urea $1,5 \%$ sebagai formulasi terbaik. Formula tersebut menghasilkan total BAL sebesar $8,6 \times 10^{6} \mathrm{CFU} / \mathrm{mL}$. Total BAL dari media alternatif lebih tinggi dibandingkan dengan kontrol MRS sebesar $1,7 \times 10^{6} \mathrm{CFU} / \mathrm{mL}$. Soygurt yang dihasilkan dari BAL hasil pertumbuhan dari media perlakuan terbaik [kulit singkong+kulit pisang $(75: 25)$ dengan penambahan urea

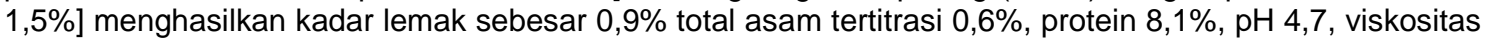
14,2 dPas, total padatan terlarut 9,7Brix, kecerahan (L) 64,3, serta warna kuning-biru (b+) 10,1. Kadar lemak, total asam tertitrasi, dan protein telah sesuai dengan SNI yogurt 2981:2009.
\end{abstract}

Kata kunci: kulit pisang, kulit singkong, Lactobacillus bulgaricus, media alternatif pertumbuhan, whey tahu

\footnotetext{
*Penulis Korespondensi:
}

E-mail: vritta@umm.ac.id 


\section{PENDAHULUAN}

Penggunaan mikroorganisme di dalam pengolahan pangan merupakan bagian penting dari ilmu bioteknologi pangan. Aplikasi dari mikroorganisme telah banyak ditemukan dalam skala laboratorium dan juga industri pada makanan dan juga minuman. Aplikasi tersebut tak lepas dari peranan proses fermentasi dalam pengolahan pangan terhadap industri, pemenuhan nutrisi, dan juga pemaksimalan sisi fungsional pada pangan (Cagno et al., 2013). Bakteri asam laktat (BAL) merupakan golongan yang berperan penting dalam pengolahan pangan seperti memberikan peningkatan pada reologi, tekstur, rasa, dan efek fisiologis lain yang baik pada makanan fermentasi (Daba et al., 2021).

Bakteri asam laktat (BAL) merupakan bakteri gram positif, bersifat anaerob, menghasilkan asam laktat $\left(\mathrm{CH}_{3} \mathrm{CHCOOH}\right)$ hasil pemecahan dari karbohidrat (Cagno et al., 2013). Secara taksonomi, terdapat empat BAL antara lain Lactobacillus, Streptococcus, Pedio-coccus, dan Leuconostoc (Von dan Axxelson, 2012). Pada pertumbuhannya, BAL membutuhkan nutrisi yang kompleks. Media pertumbuhan de man rogose and sharpe (MRS) merupakan media pertumbuhan yang spesifik untuk BAL namun memiliki harga yang relatif mahal. Rentang harga MRS agar adalah Rp 1.500.0001.800 .000 ,- per $500 \mathrm{~g}$. Hal inilah yang menjadi landasan dibutuhkan studi formulasi media alternatif untuk BAL dengan penggunaan bahan alam yang relatif lebih terjangkau.

Kunci dari formulasi media pertumbuhan BAL adalah di komposisi nutrisi yang dibutuhkan (Hayek et al., 2019). Bahan alam yang digunakan sebagai media dapat bersumber dari kulit pisang (Esivan et al., 2016), whey tahu (Nurlaela et al., 2016), limbah cair tapioka (Wulan et al., 2017), sorgum (Byakika et al., 2020), dan lain-lain. Selain bahan tersebut, kulit singkong juga berpotensi sebagai bahan media alternatif BAL.

Kulit singkong mengandung karbohidrat yang tinggi sebesar $44-59 \%$ dan protein sebesar $1,5-3,7 \%$ (Wachid dan Mutia, 2019). Penelitian sebelumnya telah memanfaatkan kulit singkong sebagai media pertumbuhan Lactobacillus sp. Hasil penelitian tersebut menunjukkan bahwa media kulit singkong dapat ditumbuhi Lactobacillus sp., namun dengan jumlah koloni yang masih sedikit. Sedikitnya kuantitas BAL tersebut diduga karena nutrisi yang dibutuhkan oleh Lactobacillus sp. belum sepenuhnya terpenuhi (Farmawan, 2014).

Nutrisi dasar yang dibutuhkan oleh BAL tidak hanya karbon $(C)$ namun juga fosfor $(P)$ dan nitrogen (N) (Hayek dan Ibrahim, 2013). Berdasarkan penelitian sebelumnya, diketahui bahwa limbah kulit pisang memiliki kandungan fosfor sebesar $117 \mathrm{mg} /$ $100 \mathrm{~g}$ (Hikmah, 2015). Kandungan nitrogen sendiri dapat diambil dari limbah cair pembuatan tahu yang biasa disebut dengan whey.

Penelitian ini bertujuan untuk mengetahui formulasi media pada media alternatif cassava banana peel whey (CBPW) yang baik untuk pertumbuhan $B A L$, tingkat keberhasilan pertumbuhan $B A L$ yang ditumbuhkan pada media CBPW, dan mengetahui viabilitas BAL yang diaplikasikan ke soygurt.

\section{BAHAN DAN METODE}

\section{Bahan}

Penelitian menggunakan kulit singkong, kulit pisang kepok, whey dari pabrik tahu di Karangploso Malang, pupuk urea, MRS (Merck, Jerman), starter BAL Lactobacillus bulgaricus, susu kedelai yang diperoleh dari pasar lokal di Landungsari Malang.

\section{Pembuatan media CBPW (Farmawan, 2014 dengan modifikasi)}

Media pertumbuhan CBPW dibuat dari limbah kulit singkong, kulit pisang, dan whey. Modifikasi yang dilakukan dari metode Farmawan (2014) adalah penambahan kulit pisang dan whey sebagai tambahan nutrisi pada media. Kulit singkong dihilangkan bagian luarnya lalu bagian berwarna putih direndam selama 24 jam. Kulit singkong ditimbang. Kulit pisang dikerok, dihilangkan bagian luarnya, kemudian ditimbang. Kulit singkong dan kulit pisang dicampurkan kemudian ditambahkan dengan whey tahu sebanyak $90 \mathrm{~mL}$. Campuran tersebut dipanaskan hingga didapatkan pelarut berkurang $50 \%(\mathrm{v} / \mathrm{v})$. Larutan disaring menggunakan kain saring hingga ampas dan ekstraknya terpisah. Ekstrak diambil sebanyak $10 \mathrm{~mL}$ kemudian ditambahkan dengan whey tahu hingga volumenya $100 \mathrm{~mL}$. Larutan ditambahkan dextrose $(1,5 \mathrm{~g})$, urea $(1 ; 1,5$; atau $2 \% \mathrm{~b} / \mathrm{b})$ dan agar-agar $(2 \mathrm{~g})$. Larutan dipanaskan hingga mendidih menggunakan hotplate sambil diaduk. Media di sterilisasi dalam autoklaf (H1CLAVE HVE-50 Hirayama, Jepang) $\left(\mathrm{t}=15\right.$ menit, $\left.\mathrm{T}=121^{\circ} \mathrm{C}\right)$. Media didinginkan hingga suhu $70^{\circ} \mathrm{C}$. Media dituang ke cawan petri kemudian dibiarkan hingga padat.

Penelitian menggunakan MRS sebagai kontrol. Media MRS (Merck, Jerman) sebanyak 6,2 g, ditambahkan akuades sebanyak $100 \mathrm{~mL}$, lalu dididihkan. Media dimasukkan dalam erlenmeyer kemudian disterilisasi $\left(\mathrm{t}=15\right.$ menit, $\left.\mathrm{T}=121^{\circ} \mathrm{C}\right)$. Media dituang ke cawan petri dan dibiarkan hingga padat. 
Isolasi BAL dan pembuatan pellet sel BAL (Hidayat et al., 2013 dengan modifikasi)

Modifikasi yang dilakukan terhadap Hidayat et al. (2013) adalah penggunaan yogurt sebagai starter. Yogurt sebanyak $1 \mathrm{~mL}$ diencerkan ke dalam $9 \mathrm{~mL}$ akuades steril. Campuran dihomogenkan menggunakan vortex. Inokulum steril kemudian digoreskan ke media kontrol MRS dan juga media alternatif kulit singkong, kulit pisang, dan whey tahu dengan metode gores sinambung. Cawan kemudian diinkubasi $\left(T=37^{\circ} \mathrm{C}, \mathrm{t}=48\right.$ jam $)$.

Pembuatan pellet dilakukan dengan memasukkan media CBPW dan MRS (kontrol) yang ditumbuhi BAL ke dalam tabung. Tabung disentrifuse (polypropylene, HDEP Blue caps, $15 \mathrm{~mL}$, Indonesia) selama 15 menit pada kecepatan 10.000 rpm hingga terpisah antara pelet sel BAL dan media tumbuh.

\section{Pembuatan soygurt (Legowo, 2009 dengan modifikasi)}

Modifikasi yang dilakukan terhadap Legowo (2009) adalah penggunaan bahan baku sari kedelai, bukan susu sebagai bahan awal soygurt. Sari kedelai dipasteurisasi menggunakan panci $\left(T=75^{\circ} \mathrm{C}\right.$, $\mathrm{t}=15$ menit) kemudian didinginkan $\left(T=43^{\circ} \mathrm{C}\right)$. Sari kedelai yang telah dingin dimasukkan dalam botol plastik steril. Pelet sel ditambahkan ke dalam sari kedelai dengan kepadatan $1,0 \times 10^{7} \mathrm{CFU} / \mathrm{mL}$, dikocok pelan, kemudian diinkubasi $\left(\mathrm{T}=25^{\circ} \mathrm{C}, \mathrm{t}=24 \mathrm{jam}\right)$. Soygurt diperoleh dari hasil fermentasi selama 24 jam tersebut.

\section{Parameter analisis}

Analisis proksimat bahan baku kulit singkong dan kulit pisang dengan kadar air dengan metode gravimetri, kadar abu, karbohidrat dengan metode by difference, kadar lemak, dan protein (BSN, 2009). Analisis fisikokimia soygurt hasil fermentasi dari BAL yang diisolasi yaitu $\mathrm{pH}$, total asam laktat, total $\mathrm{BAL}$, intensitas warna, viskositas, lemak, protein, organoleptik menggunakan uji skala hedonik (BSN, 2009). Identifikasi BAL dengan pengamatan bentuk dan warna koloni menggunakan mikroskop dengan perbesaran 40x, serta perhitungan jumlah koloni menggunakan colony counter.

\section{HASIL DAN PEMBAHASAN}

\section{Kadar proksimat bahan baku}

Bahan baku media alternatif yang digunakan pada penelitian ini adalah kulit singkong dan kulit pisang. Kulit singkong dan kulit pisang diuji proksimatnya, hasilnya tersaji pada Tabel 1.

Kandungan karbohidrat yang tinggi pada kulit singkong $(69,7 \%)$ dan pisang $(73,9 \%)$ menunjukkan bahwa keduanya berpotensi sebagai bahan baku media pertumbuhan alternatif untuk BAL. Bahan alam yang memiliki kandungan karbohidrat yang tinggi memang berpotensi sebagai bahan media alternatif untuk BAL (Endo et al., 2011). Kulit singkong diketahui dapat digunakan sebagai media alternatif pertumbuhan yeast Sacharomycess cerreviceae dengan penambahan urea dan monopotassium fosfat $\left(\mathrm{KHPO}_{4}\right)$ (Wachid dan Mutia, 2019) dan berhasil diaplikasikan ke dalam pembuatan roti (Wachid dan Mutia, 2019). Kulit pisang juga telah dimanfaatkan sebagai media Lactobacillus casei dan Lactobacillus plantarum (Kusuma dan Zubaidah, 2016).

Tabel 1. Komposisi kimia kulit singkong dan kulit pisang

\begin{tabular}{lcc}
\hline Komposisi Kimia & Kulit Singkong & Kulit Pisang \\
\hline Air (\%) & $23,4 \pm 0,2$ & $15,6 \pm 0,2$ \\
Abu (\%) & $4,9 \pm 0,1$ & $7,6 \pm 0,1$ \\
Protein (\%) & $1,1 \pm 0,1$ & $0,7 \pm 0,2$ \\
Lemak (\%) & $0,9 \pm 0,1$ & $2,1 \pm 0,1$ \\
Karbohidrat (\%) & $69,7 \pm 0,2$ & $73,9 \pm 0,1$ \\
\hline
\end{tabular}

\section{Hasil media CPBW dan MRS}

Hasil analisis ragam menunjukkan adanya interaksi $(P<0,05)$ antara perlakuan perbandingan kulit singkong dan kulit pisang serta penambahan urea terhadap total BAL. Total BAL dari media MRS (kontrol) adalah $2,2 \times 10^{6} \mathrm{CFU} / \mathrm{mL}$. Total BAL tertinggi yaitu $8,6 \times 10^{6} \mathrm{CFU} / \mathrm{mL}$ dihasilkan dari media kulit singkong:kulit pisang $(75: 25 \mathrm{~b} / \mathrm{b})$ dengan penambahan urea $1,5 \%$ (SP3U2). Kepadatan sel awal

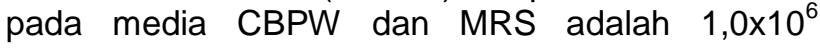
$\mathrm{CFU} / \mathrm{mL}$. HAsil perhitungan total bakteri asam laktat (BAL) pada media CPBW dan MRS tersaji pada Tabel 2.

Tingginya total BAL yang dihasilkan berhubungan dengan kecukupan nutrisi yang dibutuhkan oleh bakteri (Kim et al., 2021). BAL menggunakan kulit singkong sebagai sumber senyawa karbon (C), cairan whey tahu dan urea sebagai sumber unsur nitrogen $(\mathrm{N})$, sedangkan kulit pisang sebagai sum-ber unsur fosfor $(P)$ dan mineral lainnya. Persentase kulit singkong sebanyak $75 \%$ dengan total BAL tertinggi sesuai dengan sifat fisiologis BAL yang cenderung lebih mudah hidup pada media dengan nutrisi karbohidrat yang tinggi (Bartkiene et al., 2020).

Pengamatan bentuk dan warna koloni bakteri pada media dilakukan untuk mengidentifikasi jenis BAL yang dihasilkan. Hasil pengamatan sel yang berbentuk bacil (batang) dari Lactobacillus bulgaricus. Hasil positif juga didukung oleh hasil pewarnaan menunjukkan warna keunguan sehingga positif bakteri gram positif (Gambar 1). 
Tabel 2. Hasil total bakteri asam laktat (BAL)

\begin{tabular}{|c|c|c|}
\hline Perlakuan & Kode & $\begin{array}{l}\text { Total BAL } \\
\text { (CFU/mL) }\end{array}$ \\
\hline $\begin{array}{l}\text { Kontrol MRS (deMann } \\
\text { Ragosa Agar) }\end{array}$ & MRS & $\begin{array}{c}2,2 \pm 0,05 x \\
10^{6} \mathrm{bc}\end{array}$ \\
\hline $\begin{array}{l}\text { Kulit Singkong+Kulit Pisang } \\
(25: 75)+\text { Urea } 1 \%\end{array}$ & SP1U1 & $\begin{array}{c}1,7 \pm 0,07 x \\
10^{6} \mathrm{bc}\end{array}$ \\
\hline $\begin{array}{l}\text { Kulit Singkong+Kulit Pisang } \\
(25: 75)+\text { Urea } 1,5 \%\end{array}$ & SP1U2 & $\begin{array}{l}1,5 \pm 0,05 x \\
10^{6} \mathrm{bc}\end{array}$ \\
\hline $\begin{array}{l}\text { Kulit Singkong+Kulit Pisang } \\
(25: 75)+\text { Urea } 2 \%\end{array}$ & SP1U3 & $\begin{array}{c}1,5 \pm 0,05 x \\
10^{6} \mathrm{bc}\end{array}$ \\
\hline $\begin{array}{l}\text { Kulit Singkong+Kulit Pisang } \\
(50: 50)+\text { Urea } 1 \%\end{array}$ & SP2U1 & $\begin{array}{l}1,9 \pm 0,06 x \\
10^{6} \mathrm{bc}\end{array}$ \\
\hline $\begin{array}{l}\text { Kulit Singkong+Kulit Pisang } \\
(50: 50)+\text { Urea 1,5\% }\end{array}$ & SP2U2 & $\begin{array}{c}2,9 \pm 0,04 x \\
10^{6} \mathrm{c}\end{array}$ \\
\hline $\begin{array}{l}\text { Kulit Singkong+Kulit Pisang } \\
(50: 50)+\text { Urea } 2 \%\end{array}$ & SP2U3 & $\begin{array}{c}3,7 \pm 0,05 x \\
10^{6} d\end{array}$ \\
\hline $\begin{array}{l}\text { Kulit Singkong+Kulit Pisang } \\
(75: 25)+\text { Urea } 1 \%\end{array}$ & SP3U1 & $\begin{array}{l}3,5 \pm 0,04 x \\
10^{6} d\end{array}$ \\
\hline $\begin{array}{l}\text { Kulit Singkong+Kulit Pisang } \\
(75: 25)+\text { Urea } 1,5 \%\end{array}$ & SP3U2 & $\begin{array}{c}8,6 \pm 0,06 x \\
10^{6} \mathrm{a}\end{array}$ \\
\hline $\begin{array}{l}\text { Kulit Singkong+Kulit Pisang } \\
(75: 25)+\text { Urea } 2 \%\end{array}$ & SP3U3 & $\begin{array}{c}8,4 \pm 0,07 x \\
10^{6} a \\
\end{array}$ \\
\hline
\end{tabular}

Keterangan: Nilai rerata yang diikuti oleh huruf yang sama tidak berbeda nyata menurut uji Duncan $\alpha=5 \%$

\section{Kandungan bakteri asam laktat pada soygurt}

Total BAL soygurt dari media CPBW (SP3U2) sebesar $2,0 \times 10^{7} \mathrm{CFU} / \mathrm{mL}$, sedangkan soygurt dari

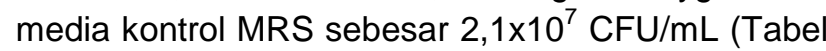
3). Kepadatan sel awal media CBPW dan MRS adalah $1,0 \times 10^{6} \mathrm{CFU} / \mathrm{mL}$. Berdasarkan hasil analisis uji $\mathrm{T} \alpha=5 \%$, tidak ada perbedaan nyata antara total BAL hasil CPBW perlakuan terbaik (SP3U2) dan kontrol (MRS). Total BAL yang tidak berbeda nyata antara keduanya menunjukkan bahwa media CPBW (SP3U2) yaitu, kulit singkong+kulit pisang (75:25 b/b)+urea $1,5 \%$ dapat menggantikan MRS sebagai media pertumbuhan BAL. Kandungan nutrisi utama yang dibutuhkan BAL yaitu karbon (C) dan nitrogen (N) (Azizah et al., 2012; Moradi et al., 2021).

Tabel 3. Mikrobiologi soygurt

\begin{tabular}{cc}
\hline Komponen & Total BAL $(\mathrm{CFU} / \mathrm{mL})$ \\
\hline Kontrol (MRSA) & $2,1 \pm 0,04 \times 10^{\prime} \mathrm{a}$ \\
Perlakuan Terbaik (CBPW) & $2,0 \pm 0,05 \times 10^{\prime} \mathrm{a}$ \\
\hline Keterangan: Nilai rerata yang diikuti oleh huruf yang sama \\
tidak berbeda nyata menurut uji T $\alpha=5 \%$
\end{tabular}

\section{Mutu kimia soygurt}

BAL hasil isolasi perlakuan terbaik (SP3U2) yaitu dari media CPBW kulit singkong+kulit pisang $(75: 25 \mathrm{~b} / \mathrm{b})+$ +urea $1,5 \%$, digunakan untuk memfermentasikan susu soya menjadi soygurt (soya yogurt). MRS digunakan pula sebagai kontrol. Soygurt dianalisis mutu kimianya kemudian dibandingkan dengan SNI yogurt (standar untuk yogurt).

Kadar lemak soygurt dari media CPBW (SP3U2) sebesar 0,9\% sedangkan soygurt yang dari media kontrol MRS sebesar 0,7\% (Tabel 4). Kadar lemak tersebut sudah sesuai dengan standar yogurt (BSN, 2009). Perbedaan antara soygurt CPBW (SP3U2) dan kontrol MRS tidak berbeda secara nyata. Lemak pada soygurt hasil akumulasi dari kandungan lemak susu kedelai. Pada proses fermentasi dari susu kedelai menjadi soygurt, kuantitas lemak tidak mengalami perubahan signifikan karena BAL memanfaatkan laktosa sebagai sumber karbon (Handayani et al., 2016).

Total asam tertitrasi soygurt dari media CPBW (SP3U2) sebesar $0,6 \%$, sedangkan soygurt dari media kontrol MRS sebesar $0,5 \%$. Angka TAT dari kedua soygurt telah sesuai SNI (BSN, 2009). Angka total asam tertritrasi menunjukkan prosentasi kandungan asam laktat yang dihasilkan oleh BAL pada proses fermentasi (Yaumi et al., 2020). Hasil TAT keduanya tidak berbeda secara nyata sehingga menunjukkan viablitas BAL keduanya hampir sama. Hal ini semakin mendukung hasil penelitian bahwa media CPBW (SP3U2) terbukti mampu menggantikan fungsi MRS.

Protein soygurt dari media CPBW (SP3U2) sebesar $8,1 \%$, sedangkan soygurt dari media kontrol MRS sebesar 10,0\%. Angka lemak dari kedua soygurt tersebut sudah sesuai dengan SNI (BSN, 2009), karena telah di atas angka $2,7 \%$. Protein soygurt hasil CPBW (SP3U2) cukup berbeda dengan kontrol MRS.

Nilai $\mathrm{pH}$ soygurt dari media CPBW (SP3U2) sebesar 4,7, sedangkan soygurt dari media kontrol MRS sebesar 4,5. Nilai pH dari kontrol MRS lebih asam dibandingkan media CPBW sesuai dengan hasil analisis total BAL. Total BAL soygurt dari me-

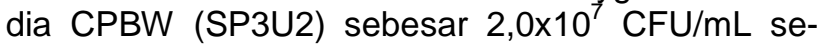
dangkan soygurt dari media kontrol MRS sebesar $2,1 \times 10^{7} \mathrm{CFU} / \mathrm{mL}$. Nilai $\mathrm{pH}$ yang dianalisis berhubungan dengan asam laktat hasil fermentasi dari sari kedelai (Gonzáles-Leos et al., 2020). Minuman fermentasi dengan kualitas yang baik memiliki $\mathrm{pH}$ 3,8-4,6. Soygurt dengan nilai $\mathrm{pH}$ 4,0-5,0 menunjukkan viabilitas BAL yang baik karena menghasilkan asam laktat yang baik pada proses fermentasinya (de Oliveira et al., 2020).

\section{Mutu fisika soygurt}

Soygurt dari media CPBW (SP3U2) dianalisis mutu fisika soygurt meliputi analisis viskositas, total padatan terlarut (TPT), kecerahan (L), dan warna kuning-biru $(b+)$. Kontrol menggunakan media MRS. 


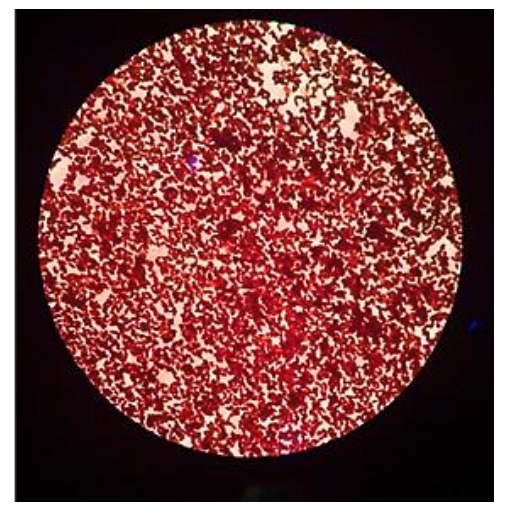

A

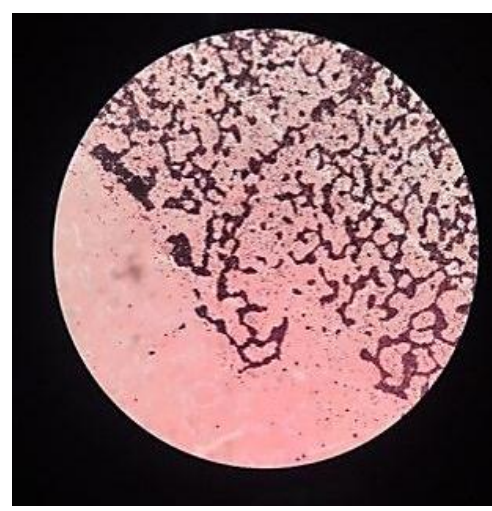

D

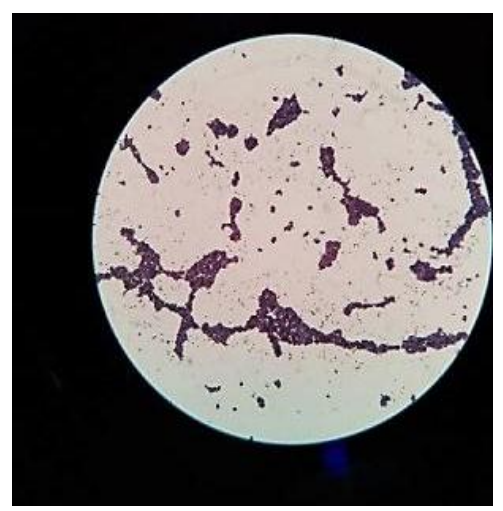

G

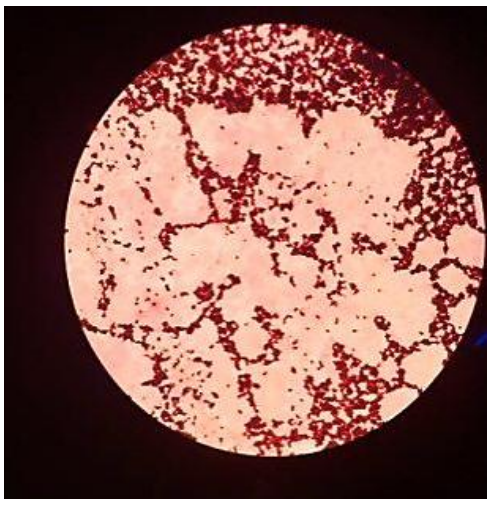

B

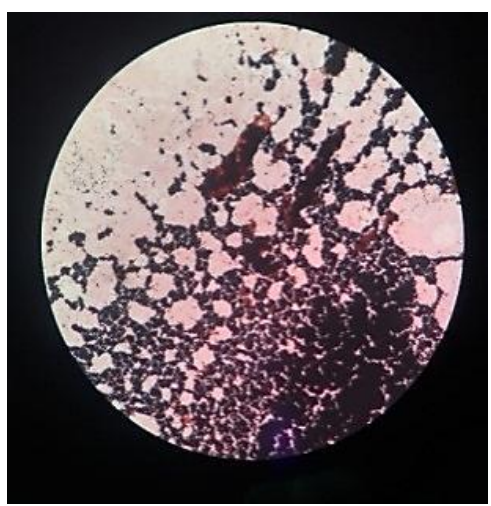

E

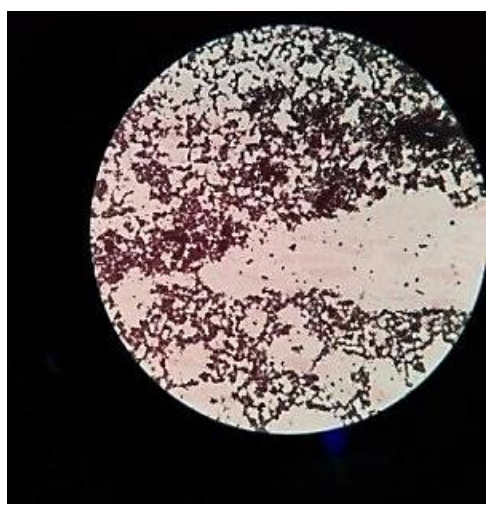

H

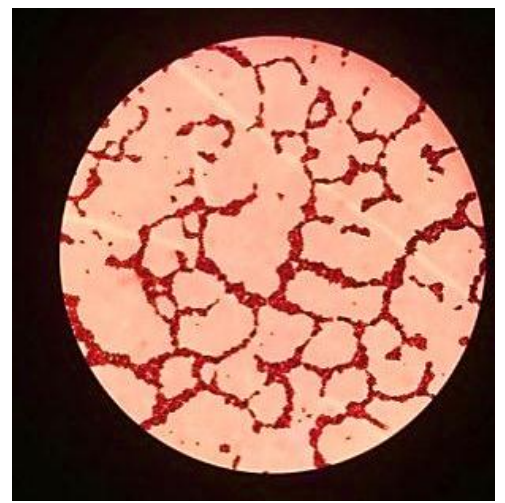

C

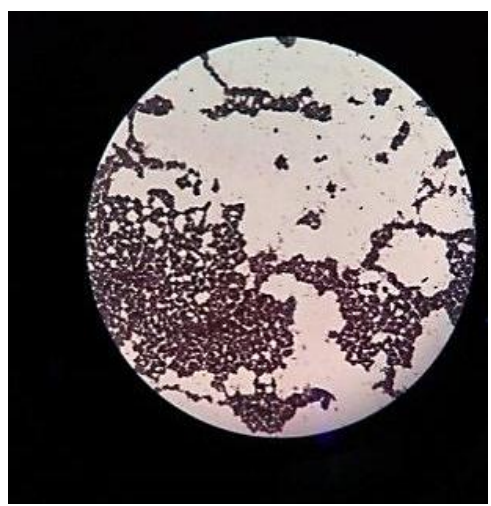

$\mathbf{F}$

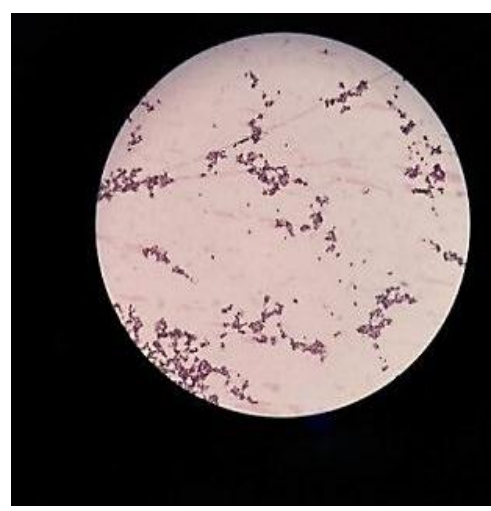

I

keterangan: A=SP1U1; $B=S P 1 U 2 ; C=S P 1 U 3 ; D=S P 2 U 1 ; E=S P 2 U 2 ; F=S P 2 U 3 ; G=S P 3 U 1 ; H=S P 3 U 2 ; I=S P 3 U 3$; Menggunakan mikroskop dengan perbesaran $40 \mathrm{x}$

Gambar 1. Bentuk dan pewarnaan koloni

Viskositas soygurt dari media CPBW (SP3U2) sebesar 14,2 dPas, sedangkan soygurt dari media kontrol MRS sebesar 14,3 dPas. Viskositas meningkat dengan semakin tingginya kandungan sukrosa pada soygurt. Sukrosa yang cukup tinggi, akan menghasilkan soygurt yang memiliki rata-rata viskositas tinggi. Komponen terlarut yang semakin besar dalam suatu larutan akan meningkatkan viskositas (Khalid, 2011).

Total padatan terlarut (TPT) soygurt dari media CPBW (SP3U2) sebesar $9,7^{\circ}$ Brix, sedangkan soygurt dari media kontrol MRS sebesar 9,0 Brix. TPT diukur dengan satuan ${ }^{\circ}$ Brix yang berarti jumlah massa per $100 \mathrm{~g}$. TPT dari soygurt BAL hasil per- 
tumbuhan dari media perlakuan terbaik (SP3U2) yaitu $9,7^{\circ}$ Brix artinya terdapat $9,7 \mathrm{~g}$ dalam $90,3 \mathrm{~g}$ pelarut. TPT dari soygurt BAL hasil pertumbuhan dari media kontrol MRS yaitu $9,0^{\circ}$ Brix artinya terdapat $9,0 \mathrm{~g}$ dalam $90,0 \mathrm{~g}$ pelarut. Angka TPT biasanya linier dengan tingkat keasaman dari yogurt karena berhubungan dengan pertumbuhan $\mathrm{BAL}$ di dalamnya (Özer dan Kılıç, 2021). Pertumbuhan BAL akan meningkatkan aktifitas koagulasi protein dari sari kedelai sehingga linier dengan peningkatan total padatan (Burssens, 2011).

Intensitas warna dianalisis menggunakan colour reader dinyatakan dengan nilai kecerahan (L), hijau-merah (a), biru-kuning (b). Pada penelitian ini, intensitas warna soygurt yang dianalisis yaitu kecerahan (L) dan intensitas biru-kuning (b). Nilai L menunjukkan tingkat kecerahan. Nilai kecerahan rentangnya $1-100$, semakin mendekati angka 1 maka semakin gelap sampel, namun semakin mendekati 100 maka semakin cerah sampel. Nilai tinggi $\mathrm{L}$ artinya warna soygurt semakin cerah sedangkan jika nilai $L$ semakin rendah artinya soygurt semakin gelap. Nilai b menunjukkan rentang warna kuninghijau. Semakin tinggi angka b, intensitas warna kuning soygurt semakin kuat.

Berdasarkan Tabel 5 , intensitas warna kuning $(b+)$ dari soygurt dari BAL hasil pertumbuhan dari media perlakuan terbaik (SP3U2) yaitu 10,1 , sedangkan hasil dari media kontrol MRS sebesar 10,0. Angka tersebut menunjukkan bahwa intensitas warna kuning dari soygurt yang dihasilkan rendah. Hal ini berhubungan dengan warna pigmen alami dari bahan baku kedelai.

\section{Mutu organoleptik soygurt}

Uji organoleptik terdiri atas aroma, warna, tekstur (kekentalan), dan kenampakan. Penilaian dilakukan oleh 30 orang panelis tidak terlatih. Nilai yang dilaporkan adalah nilai rataan dari jumlah panelis tersebut. Rentang penilaian hedonik: (1) sangat tidak suka, (2) tidak suka, (3) netral, (4) suka dan (5) sangat suka. Data kemudian dianalisis dengan uji T $\alpha=5 \%$ (Tabel 6 ).

Meski nilai uji organoleptik (aroma, warna, kekentalan, dan kenampakan) soygurt hasil MRS (kontrol) lebih tinggi dari segi memiliki nilai yang lebih tinggi untuk soygurt hasil CPBW, perbedaan nilai keduanya tidaklah nyata. Hal ini menunjukkan bahwa soygurt hasil CPBW (SP3U2) dan MRS (kontrol) dapat diterima dari segi organoleptik (hedonik).

\section{KESIMPULAN}

Media alternatif pertumbuhan bakteri asam laktat dapat dibuat dari komposisi limbah kulit singkong, kulit pisang, dan whey tahu (cassava banana peel whey) berpotensi dapat menggantikan media MRS. Berdasarkan jumlah total BAL, diperoleh formulasi terbaik yaitu kulit singkong+kulit pisang (75:25) dengan penambahan urea 1,5\%. Total BAL dari media alternatif terbaik sebesar $8,6 \times 10^{6} \mathrm{CFU} / \mathrm{mL}$, lebih tinggi dibandingkan media kontrol MRS sebesar $1,7 \times 10^{6} \mathrm{CFU} / \mathrm{mL}$. Soygurt dengan BAL hasil isolasi dari media formulasi terbaik menunjukkan kadar lemak, total asam tertitrasi, dan protein yang sesuai dengan SNI yogurt.

Tabel 4. Mutu kimia soygurt

\begin{tabular}{lcccc}
\hline \multicolumn{1}{c}{ Komponen } & Lemak (\%) & Total Asam Tertitrasi (\%) & Protein (\%) & $\mathrm{pH}$ \\
\hline Kontrol (MRS) & $0,7 \pm 0,02^{\mathrm{a}}$ & $0,5 \pm 0,03^{\mathrm{a}}$ & $10,0 \pm 0,07^{\mathrm{a}}$ & $4,5 \pm 0,02^{\mathrm{a}}$ \\
Perlakuan terbaik (CBPW) & $0,9 \pm 0,02^{\mathrm{a}}$ & $0,6 \pm 0,03^{\mathrm{a}}$ & $8,1 \pm 0,07^{\mathrm{b}}$ & $4,7 \pm 0,02^{\mathrm{b}}$ \\
SNI (Yogurt rendah lemak) & $0,6-2,9$ & $0,5-2,0$ & Min $2,7^{2,0}$ & \\
\hline
\end{tabular}

Keterangan: Nilai rerata yang diikuti oleh huruf yang sama tidak berbeda nyata menurut uji $\mathrm{T} \alpha=5 \%$

Tabel 5. Mutu fisika soygurt

\begin{tabular}{lcccc}
\multicolumn{1}{c}{ Komponen } & Viskositas (dPas) & $\begin{array}{c}\text { Total Padatan } \\
\left.\text { Terlarut ( }{ }^{\circ} \text { Brix }\right)\end{array}$ & Kecerahan (L) & $\begin{array}{c}\text { Warna Kuning-Biru } \\
(\mathrm{b}+)\end{array}$ \\
\hline Kontrol (MRS) & $14,3 \pm 0,05^{\mathrm{a}}$ & $9,0 \pm 0,06^{\mathrm{a}}$ & $64,4 \pm 0,02^{\mathrm{a}}$ & $10,0 \pm 0,02^{\mathrm{a}}$ \\
Perlakuan Terbaik (CBPW) & $14,2 \pm 0,04^{\mathrm{b}}$ & $9,7 \pm 0,08^{\mathrm{a}}$ & $64,3 \pm 0,02^{\mathrm{a}}$ & $10,1 \pm 0,02^{\mathrm{a}}$ \\
\hline
\end{tabular}

Keterangan: Nilai rerata yang diikuti oleh huruf yang sama tidak berbeda nyata menurut uji $\mathrm{T} \alpha=5 \%$

Tabel 6. Mutu organoleptik soygurt

\begin{tabular}{lcccc}
\hline Komponen & Aroma & Warna & Kekentalan & Kenampakan \\
\hline Kontrol (MRS) & $3,9 \pm 0,1^{\mathrm{a}}$ & $4,2 \pm 0,1^{\mathrm{a}}$ & $3,6 \pm 0,1^{\mathrm{a}}$ & $3,3 \pm 0,1^{\mathrm{a}}$ \\
Perlakuan Terbaik (CBPW) & $3,5 \pm 0,1^{\mathrm{a}}$ & $3,9 \pm 0,1^{\mathrm{a}}$ & $3,3 \pm 0,1^{\mathrm{a}}$ & $3,0 \pm 0,1^{\mathrm{a}}$ \\
\hline
\end{tabular}

Keterangan: Nilai rerata yang diikuti oleh huruf yang sama tidak berbeda nyata menurut uji $\mathrm{T} \alpha=5 \%$ 


\section{DAFTAR PUSTAKA}

Azizah N, Barrii AN, Mulyani S. 2012. Pengaruh lama fermentasi terhadap kadar alkohol, ph, dan produksi gas pada proses fermentasi bioethanol dari whey dengan substitusi kulit nanas. J Aplikasi Teknol Pangan 1: 72-77.

[BSN] Badan Standardisasi Nasional. 2009. SNI 2981: Yogurt. Badan Standardisasi Nasional, Jakarta.

Bartkiene E, Lele V, Ruzauskas M, Domig KJ, Starkute V, Zavistanaviciute $P$, Bartkevics V, Pugajeva I, Klupsaite D, Juodeikiene G, Mickiene R, Rocha JM. 2020. Lactic acid bacteria isolation from spontaneous sourdough and their characterization including antimicrobial and antifungal properties evaluation. Microorganisms 8: 64-83. DOI: $10.3390 /$ microorganisms 80100 64.

Burssens S, Pertry I, Ngudi DD, Kuo YH, Montagu MV, Lambein F. 2011. Soya, human nutrition and health, soybean and nutrition. Intech 1: 157-180. DOI: 10.5772/21951.

Byakika S, Mukisa IM, Byaruhanga YB. 2020. Sorghum malt extract as a growth medium for lactic acid bacteria cultures: A case of Lactobacillus plantarum MNC 21. Int J Microbiol 1: 1-7. DOI: 10.1155/2020/6622207.

Cagno RD, Coda R, Angelis MD, Gobbeti M. 2013. Exploitation of vegetables and fruits through lactic acid fermentation. Food Microbiol 33: 110. DOI: 10.1016/j.fm.2012.09.003.

Daba GM, Elnahas MO, Elkhateeb WA. 2021. Contributions of exopolysaccharides from lactic acid bacteria as biotechnological tools in food, pharmaceutical, and medical applications. Int $\mathrm{J}$ Biol Macromol 173: 79-89. DOI: 10.1016/j. ijbiomac.2021.01.110.

de Oliveira RA, Kormesu A, Rossell CEV, Maciel MRW, Filho RM. 2020. A Study of the residual fer-mentation sugars influence on an alternative downstream process for first and secondgeneration lactic acid. Sustain Chem Pharm 15: 1-5. DOI: 10.1016/j.scp.2019.100206.

Endo A, Futagawa-Endo Y, Dicks LMT. 2011. Influence of carbohydrates on the isolation of lactic acid bacteria. J Appl Microbiol 110: 10851092. DOI: 10.1111/j.1365-2672.2011.04966.x.

Esivan SMM, Rashid R, Zaharudin NA, Mahmood, NAN. 2016. Growth and survival of Lactobacillus casei in rice bran and banana peel medium. Int J Nano Biomater 6: 151-161. DOI: 10. 1504/IJNBM.2016.086107.

Farmawan R. 2014. Pemanfaatan Limbah Kulit Singkong (Manihot esculenta Pohl) sebagai
Media Pengganti Potato Dextrose Agar (PDA) Bagi Pertumbuhan Mikroorganisme. [Skripsi]. Malang: Fakultas Pertanian-Peternakan, Universitas Muhammadiyah Malang.

Gonzáles-Leos A, Bustos MG, Rodríguez-Castillejo GC, Durán LVR, Del Ángel JADÁ. 2020. Kinetics of lactic acid fermentation from sugarcane bagasse by Lactobacillus pentosus. Revista Mexicana De Ingeniería Química 19: 377386. DOI: 10.24275/rmiq/Alim618.

Handayani MN, Wulandari P. 2016. Pengaruh penambahan berbagai jenis susu terhadap karakteristik soygurt. Agrointek 10: 62-64. DOI: 10.21107/agrointek.v10i2.2467.

Hayek SA, Gyawali R, Aljaloud SO, Krastanov A, Ibrahim SA. 2019. Cultivation media for lactic acid bacteria used in dairy products. J Dairy Res 86: 490-502. DOI: 10.1017/S00220299190 0075X.

Hayek SA, Ibrahim SA. 2013. Current limitations and challenges with lactic acid bacteria - a review. Food Nutr Sci 4: 73-87. DOI: 10.4236/fns.2013. $411 \mathrm{~A} 010$.

Hidayat I, Kusrahayu, Mulyani S. 2013. Total bakteri asam laktat, nilai $\mathrm{pH}$ dan sifat organoleptik drink yogurt dari susu sapi yang diperkaya dengan ekstrak buah mangga. Anim Agric J 2: 160-167.

Hikmah N. 2015. Pemanfaatan Limbah Kulit Pisang Ambon (Musa Paradisiacal) Dalam Pembuatan Plastik Biodegradable Dengan Plasticizer Gliserin. [Tesis]. Palembang: Teknik Kimia, Politeknik Negeri Sriwijaya.

Khalid K. 2011. An overview of lactic acid bacteria. Int J Biosci 1: 1-13. DOI: 10.1201/b11503-2.

Kim D, Lee KD, Choi KC. 2021. Role of LAB in silage fermentation: Effect on nutritional quality and organic acid production-An overview. AIMS Agr Food 6: 216-234. DOI: 10.3934/agrfood.20 21014.

Kusuma VJM, Zubaidah E. 2016. Evaluasi pertumbuhan Lactobacillus casei dan Lactobacillus plantarum dalam medium fermentasi tepung kulit pisang. J Pangan Agroind 4: 100-108.

Legowo A, Kusrahayu, Mulyani S. 2009. Teknologi Pengolahan Susu. 20-25. UNDIP Press, Semarang.

Moradi M, Molaei R, Guimarães JT. 2021. A review on preparation and chemical analysis of postbiotics from lactic acid bacteria. Enzyme Microb Tech 143: 1-50. DOI: 10.1016/j.enzmictec. 2020.109722.

Nurlaela S, Sunarti TC, Meryandini A. 2016. Formula media pertumbuhan bakteri asam laktat Pediococcus pentosaceus menggunakan subs- 
trat whey tahu. J Sumberdaya Hayati 2: 31-38. DOI: 10.29244/jsdh.2.2.31-38.

Özer CO, Kılıç B. 2021. Optimization of pH, time, temperature, variety and concentration of the added fatty acid and the initial count of added lactic acid Bacteria strains to improve microbial conjugated linoleic acid production in fermented ground beef. Meat Sci 171: 108303. DOI: 10. 1016/j.meatsci.2020.108303.

Von WA, Axelsson L. 2012. Lactic Acid Bacteria: an Introduction. In: Lahtinen S, Ouwehand AC, Salminen S. Von WA. Lactic Acid Bacteria: Microbiological and Functional Aspects, 4th Edition. 1-16. CRC Press, Tayor \& Francis
Group LLC, Boca Raton. DOI: 10.1201/b115032.

Wachid M, Mutia P. 2019. Optimasi media kulit singkong pada pertumbuhan Sacharomyces cerreviceae. J IImiah Teknik Sipil Teknik Kimia 4: 92-101. DOI: 10.33366/rekabuana.v4i2.1280.

Wulan R, Meryandini A. Sunarti TC. 2017. Potensi limbah cair industri tapioka sebagai media pertumbuhan starter bakteri asam laktat Pediococcus pentosaceus E.1222. J Sumberdaya Hayati 3: 27-33. DOI: 10.29244/jsdh.3.1.27-33.

Yaumi, Hadju R, Yelnetty A, Lontaan NN. 2020. Kualitas sensoris yogurt sinbiotik menggunakan pati termodifikasi dari umbi uwi ungu (Dioscorea alata). Zootec 40: 196-206. DOI: 10.3579/ zot.40.1.2020.26953. 